\title{
On the edge of new public spaces - city-centre renewal and exclusion in Kaposvár, Hungary
}

\author{
VikTor ERnó JÁMBOR ${ }^{1}$ and Katalin VEDRÉDI ${ }^{1}$
}

\begin{abstract}
In this paper we intend to analyse the effects of European and Hungarian urban policies with special attention to the consequences of neoliberalisation on marginalised groups. In the first part we demonstrate how neoliberalisation evolved in Hungarian policies. Next we analyse the revanchist turn of urban rehabilitation programmes, then we demonstrate the strengthening exclusion mechanisms of the rehabilitation projects through a case study in Kaposvár (Hungary) where anti-homeless regulations changed the survival strategies of marginalised people. With this research we intended to answer two questions. Firstly, how the class relation reproduction projects and processes of the neoliberal urban policies appeared in the Hungarian policies? And, secondly, how the processes that can be linked with inner-city regeneration can be interpreted in the light of the use of public spaces and the survival strategies of homeless? We illustrate the above mentioned local changes and the discourse of exclusion (as Hungarian manifestation of revanchist urbanism) through a case study. The research is based on narrative and life-path interviews with homeless of Kaposvár, and with experts, as well as members of the local political and cultural elite. Furthermore, we made participant observations to observe the consequences of the aspirations of local political elite.
\end{abstract}

Keywords: neoliberalism, displacement, revanchist urban policy, anti-homeless law, post-socialist city, Hungary

\section{Introduction}

Neoliberalism - the dominant political theory of the late modern societies - is present in many socio-economic decisions of the contemporary world at all geographical scales (Leitner, H. 1990; Mitchell, D. and Heynen, N. 2007). The neoliberal transformation of European urban policy has also become part of this globally prevailing process since the beginning of the 1990s. Neoliberal political principles - focusing on individual freedom and on the role of market mechanism in forming social processes - have become prevalent in East Central Europe (ECE) in the late 1980s and early 1990s as part of the post-socialist transition (BocKMANN, J. and EyAL, G. 2002). According to neoliberal principles that became dominant in the USA and
UK in the early 1980s the age of welfare state expired and was replaced by a state that ensures the enforcement of market mechanisms and focuses on individual interests and responsibility. The declared goal of the national and local economic and political elites is to improve the competitiveness of cities in the global flows (WACQUANT, L. 2012), even if subordinating existing social problems to this goal (Swyngedouw, E. et al. 2002; RACO, M. 2014). In this political-institutional context welfare is provided only for those who are able to raise its terms for themselves (workfarist state) WACQUANT, L. 2009, 2014). Those who cannot do this are forced to the edge of urban societies without hardly any relevant responses that would at least partly solve their problems (e.g. unemployment, poverty, homelessness).

\footnotetext{
${ }^{1}$ University of Szeged, Department of Economic and Social Geography, H-6722 Szeged, Egyetem u. 2.

E-mail: jambor.viktor@gmail.com,E-mail: vedredikata@gmail.com
} 
Critical scholars put the "workfare state" in the very centre of their critique on neoliberalism recently. They consider the neoliberal state as a driver of uneven development (Smith, N. 2008), and this role manifests in prioritising capital accumulation in policymaking - such as employing urban development schemes to stimulate investments in the local economy. They pointed out that neoliberalism has created new forms of socio-spatial inequalities, consequently, space is increasingly divided among urban residents according to class (e.g. gender, race, sexual orientation and access to housing) (DAvis, M. 1992; Davis, M. 2006; WACQUANT, L. 2007; Belina, B. 2011; Bernt, M. and Colini, L. 2013; Kuehn, M. and Bernt, M. 2013; Ivanics Zs. 2013; NAGY, E. et al. 2015).

In this paper we analyse the effects of neoliberalisation on Hungarian urban policies focusing on the marginalised groups of the local society with special attention on the effects of urban renewal programmes and the concomitant social exclusion. We intend to answer two questions. Firstly, how neoliberal urban policies appeared in the Hungarian context? Secondly, how the processes generated by these policies can be interpreted in the light of the use of public spaces and the changing survival strategies of homeless people? We illustrate the role of local changes and the discourse of exclusion (as Hungarian manifestation of revanchist urbanism) through a case study carried out in a Hungarian medium sized town: Kaposvár. We analyse the efforts of the local political and economic elite to increase the competitiveness of the city through the regeneration of the historical inner-city, and the effects of this on the most vulnerable members of the society. We provide an overview about the local systematic - revanchist - policy-making processes which made significant part of the city-centre forbidden zone for the homeless. We analyse the aspirations of the local elite and the changing strategies of the homeless to criminalisation and penalty policies with using participatory observations, life-path and expert interviews (WACQUANT, L. 1996, 1999a,b, 2001, 2008a,b, 2014).

\section{Research methodology}

As the subject of public spaces is complex and often generates dilemmas and debates among experts the selection of right methodology was crucial. In order to get a deeper understanding of the place qualitative methods were used. By using qualitative methods it was possible to understand the processes in a deeper way. It is more flexible than quantitative methods as the research plan and the research process can be modified in accordance with the results (BABbie, E. 2001; SteInAR, K. 2005), so it can be adjusted when changing the course of the research context (Mason, J. 2005). Thereby, the application of qualitative methods enabled us to understand the transformation of public spaces and the effects of new developments. According to Letenyei (2004) during the research public spaces the best practice is when researchers take into consideration characteristics of the existing use of space which is based on observations. Therefore, in the empirical phase of the research, we conducted a field survey during which we did photo documentation. With participatory observations we explored the characteristics of the use of public spaces in a Hungarian medium-sized town, Kaposvár. The areas of observation were the inner-city falling under prohibiting regulations (Noszlopy Gáspár street and main square), an industrial area (named Nosztra) and supermarkets, where begging is taking place. The observations were made in the summer of 2015. In addition, we also visited the shelters of the homeless and the selective delivery points.

During observations we noted the gender and age of the square users and the activities they performed, the atmosphere of the observed area and the happenings. We recorded everything and we took photos. Participant observation can help us to explore the problems of the analysed area and to recognise the different ways of use (MADDEN, K. 2005; Letenyei L. 2006).Besides the field-survey nine in-depth interviews were conducted between March and September 2015. Among the interview partners were four experts (i.e. 
leader of the public space surveillance, the chief architect, a social worker and a politician), in addition we made five more lifepath interviews with homeless people (local homeless, excluded homeless, homeless who lives next to the inner city, homeless who is directly affected and a homeless who was found through a social worker).

\section{Neoliberal turn of Hungarian urban policy}

As part of the transition neoliberal approaches towards economic and social issues became dominant in the post-socialist countries of East Central Europe. According to Eyal and Bockman (2002) the "success" of neoliberal thinking should be looked for in specific actor networks and in specific transition strategies. The aim of these strategies and policies was to create stability and increase the competitiveness of the economy. After 1990 the post-socialist governments started economic reforms based on neoliberal principals across East Central Europe, and their aim was to rearrange the economy through fast liberalisation of the market and privatisation (HIRT, S. 2013; HirT, S. et al. 2013). Urban economic policies played a central role in the above mentioned processes (LeEs, L. 1994, 2000; SмITH, N. 1996; Sassen, S. 1996; Macleod, G. 2011).

The general socio-economic contexts of urban policies also substantially changed in Hungary after the change of regime. The embedding of the domestic market into globally organised production networks and the shift from a redistributive state towards a regulative one raised uncertainty within the society and heavy social conflicts such as growing unemployment, social polarisation, the spread of poverty that had to be managed locally (HARveY, D. 1989, 2005, 2006; Brenner, N. 2009). On the one hand, the city appeared in policy discourses as the scene of global competition, and on the other hand, as a relevant scale for handling social tensions. This reflected the socio-economic processes of the post-socialist transition and the neolib- eralisation of the EU policies which could be observed in the urban orientation of spatial policies, thus, the problematisation of urban transformation (JEssop, B. 2002; HARvEY, D. 2005; Brenner, N. 2009; Nagy, E. and Timár, J. 2010). Discourses related to European cities consider the city as the scene of culture, consumption and knowledge (e.g.: ESDP ${ }^{3}$, Leipzig Charter $\left.{ }^{4}\right)$. The "urban renaissance" is not only the tool, but the engine of the economic renewal.

Hungarian cities are also the targets of this neoliberal programme, where the city has become a commodity as well, and not only the cultural content but the urban space and the movements of citizens (SoJA, E. 2000, 2010). Urban space has become the subject of (symbolic) consumption for the citizens too and this has appeared in the everyday routines of people (e.g. choosing the place of residence, consumption habits, protecting public spaces) in line with the global urban trends (Sмith, N. 1996; Shields, S. 2012). In addition, the city has been reinterpreted as an economic actor too: the "entrepreneurial city" has appeared in supporting the operation of capital and started to play important role as promoting investments that transform urban spaces. At the same time institutional practices have also changed in Hungary, for example due to the fast transformation of local regulations. Local elites has reinterpreted this as an inevitable result of economic revival (NAGY, E. 2005). The downsides (actually products) of transformation: the spatial polarisation and the increase of the informal economy have been interpreted as incremental problems in this context just like in the United States or in the United Kingdom (Harvey, D. 1989). All these were reflected by local strategies and planning, by urban policies and by the introduction of exceptional measures in planning (Swyngedouw, E. et al. 2002; NagY, E. and Timár, J. 2010).

\footnotetext{
${ }^{3}$ http://ec.europa.eu/regional_policy/sources/ docoffic/official/reports/pdf/sum_en.pdf (download 2016.07 13.)

${ }^{4} \mathrm{http}$ ://ec.europa.eu/regional_policy/archive/themes/ urban/leipzig_charter.pdf (download: 2016.07.13.)
} 
However, many groups, actually the majority of the local residents play a marginal role in forming urban discourses. Despite the fact that after the transition the individual's role and influence has fundamentally changed in Eastern Central Europe in forming the daily social practices and everyday life spaces. However, local societies became less able to convert the "rules of the game" in daily practices despite the fact that the adoptions of EU development principals have demanded the active participation of local residents, public-private partnership and transparency of urban policies (Földi, Zs. 2009). Certain social problems (e.g. homelessness) were interpreted as "urban" problems, and these issues were defined and associated with urban spaces by policy-makers (MitcheLl, D. 1997; LynCh, P. 2002; Mahs, J. 2005; O'Sullivan, E. 2007; Misetics, B. 2010).

For the sake of analysis we distinguish two types of public spaces. On the one hand, the consumption spaces of the elite and the middle class - the highly appreciated spaces - and, on the other hand, the marginalised spaces (e.g. abandoned industrial buildings, empty inner-city buildings, public spaces under bridges) that are untouched by gentrification and can be used as temporary shelter by the homeless. According to SNOw, D. and Anderson, L. (1993) there is continuity between highly appreciated and marginal spaces, spatial definitions and meanings and values attached to those are constantly changing and are subject of debate. Processes of marginalisation decrease the extent of marginal spaces and make homeless peoples everyday surviving strategies uncertain (MAY, J. 2000). With developing marginal spaces homeless people are increasingly forced to use highly appreciated spaces so they get into contact with citizens who have a home (FELDMAN, L. 2006).

Urban policies tend to increasingly focuse on public spaces (NeAL, Z.P. 2010). They are intended to facilitate the return of capital with tools like renewal of the historical city centre, local tax policies and with changing the building regulations. However, the elimination and treatment of social problems in valuable urban areas are taking place with new practices (e.g. spatial banishment, changes in local regulations, eviction) (MitchelL, D. 1995; Ellickson, C.R. 1996; Bell, E. 2011). Therefore, the city as the platform (tool) of capital accumulation becomes the focus of policies and the interconnected interventions of the state basically serve the growth of competitiveness (МоLотсн, H. 1976; Harvey, D. 1989; Cox, K.R.1998).

In our opinion, the political, economic and cultural elite wishes to reproduce the national and local class structure with the neoliberal urban policy tools. The interventions of the central and local state in the spatial processes serve to reproduce the existing social (power) relations and revanchist urban policy has a major role in these processes in Hungary too. Within this framework the elite uses the projects for physical renewal of the historical city centres for revalorisation through reinvestment as part of a top-down revolution (Smith, N. 1996; MacLeod, G. 2002). It can be also observed in the practices of the institutions carrying out the interventions, in the explicit goals of the projects and the results that clearly show growing social polarisation (Smith, N. 1996; Timár, J. and NAgy, E. 2007).

Thus, neoliberalisation processes in the urban policy arrangements could clearly be observed in Hungary after the transition. The social consequences of these policies aiming at boosting urban economies were considered secondary and no comprehensive concepts were prepared to deal with them neither at the local nor at the national level. This became especially obvious in the projects designed to renew the historical city centres which have resulted in social polarisation, exclusion and the edging out of the strongly marginalised groups of the society (e.g. homeless) from these places (MitchelL, D. 1997; Waceuant, L. 2001, 2009; Tosi, A. 2007; Bence, R. and Udvarhelyi, É.T. 2013; UDVARHELYI, É.T. 2013). 


\section{Urban rehabilitation and displacement}

The reproduction of social relations by urban rehabilitation programmes in Hungary

As a result of new urban policies and government arrangements urban space has become strongly neoliberalised in Hungary in the past decades. Manifestations of the process are urban development and rehabilitation plans and related institutional practices. The local elite has interpreted urban development as a synonym of economic development so the primary aim of urban development projects were to boost local economy at the expense of social sustainability (Kovács, Z. 2009; KovÁcs, Z. et al. 2013, 2015; KovÁcs, Z. and Szabó, B. 2015; Szelényi, I. and Csillag, T. 2015). These local efforts were also encouraged by national development policies and various EU programmes (the latter as the primary source of funding).

Urban rehabilitation projects have become symbolic parts of urban governance in the neoliberal era. They have contributed to the polarisation of urban societies and the exclusion of certain groups, while they should have promoted social integration and cohesion. Cities are not only the platforms of creativity and innovation but also (increasingly visibly) spaces of social conflicts (like exclusion or marginalisation). However, repositioning urban spaces in urban competition resulted in the transformation of urban spaces for the interests of local elites, investors, developers, and tourists. City rehabilitation projects have become the tools of the elites in Hungary too, in the belief that the renewal of the historical city centre can be the engine of local economic development and through explicit aims the power position of the elite will be reproduced too (MACLeOD, G. 2011). So these projects basically reflect the classbased urban policy ideas of the elite and the power struggles for implementing them affected such fundamental rights like housing, access to services or even the free use of public spaces (Udvarhelyi, É.T. 2013).
Urban rehabilitation projects have focused on well defined geographical areas since the middle of the 2000s' in Hungary. The aims of these projects were primarily to boost urban economy and the social problems were wished to be handled by them too. However, due to the shortcomings of the projects integrity (lack of connection to the overall development of the city, and overall enforcement of social interests), the social and spatial effects of these projects, were selective and detrimental to many people (NAGY, E. 2012). At the same time the practices of implementation and its institutional framework has also radically transformed, urban renewal interventions developed new forms of local governance which became less democratic and more driven by the interests of the local economic, cultural and political elites. This was reflected in the fact that the participation of local people became formal in the judgment of responses given to social problems and possible interventions. At the same time some movements (i.e. City is for all) succeeded in drawing the attention of public to the problems of marginalised groups and individuals (LefEbrve, H. 1995).

\section{Revanchist city rehabilitation and survival strategies of the marginalised groups in Kaposvár}

In this section we illustrate how inequalities are reproduced by revanchist (neoliberal) political discourses through regulations focusing on the accessibility of the historic innercity in Kaposvár. The physical renewal of the historical city centre by the elite entailed the appearance of tools of revanchist urbanism and the use of the principle of zero tolerance (Smith, N. 1996; Cochrane, A. 2007; Massey, D. 2008). The local political and economic elite used the renewal of the historical city centre as a tool to prevent by law the use of the urban core for the most marginalised group of the local society - the homeless (Mitchell, D. 1997) (Photo 1).

In Kaposvár - just like in other cities that engaged with anti-homeless policies - local 


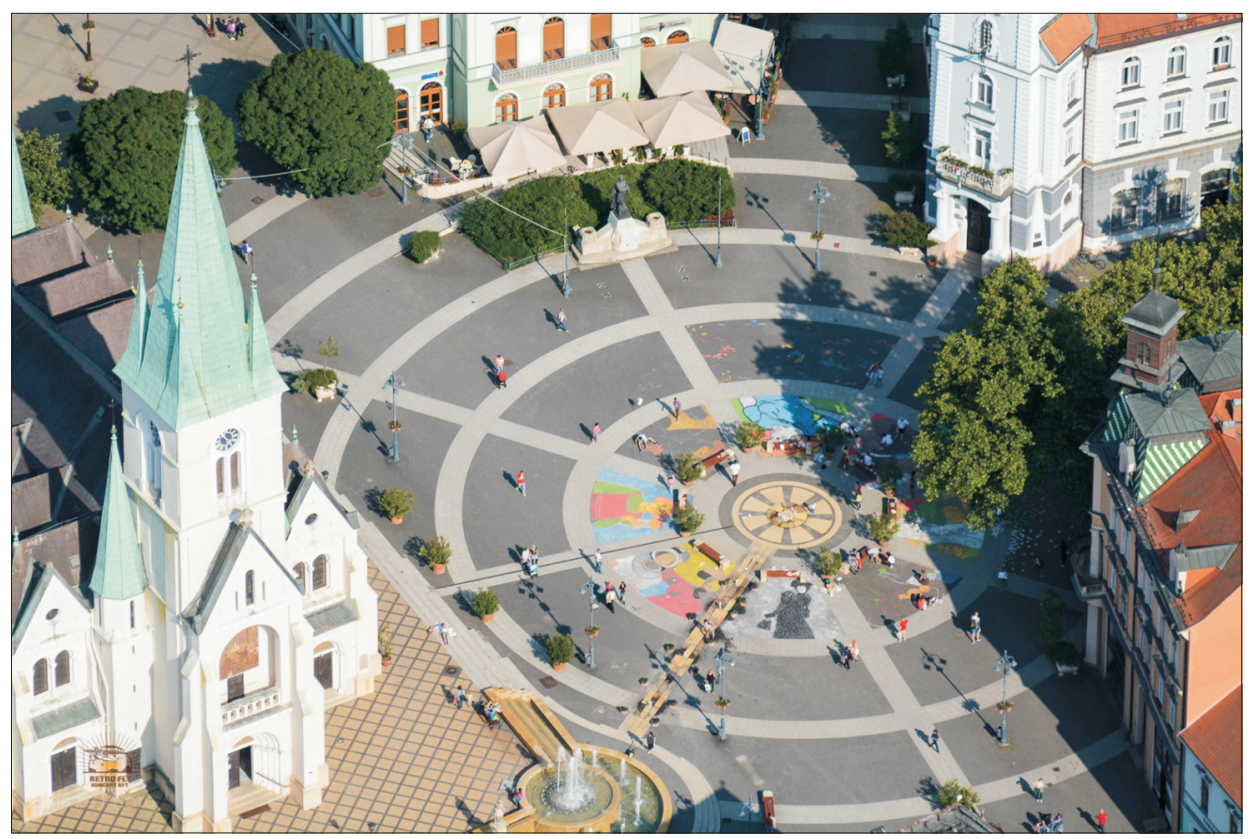

Photo 1. The renovated main square in Kaposvár

stakeholders constantly reconstruct space according to their socio-economic and political interests (HarveY, D. 2006; VÁRAdI, M. and VIRÁG, T. 2015). This can be well observed in the implementation of city renewal projects founded mainly by the EU where such processes like exclusion of homeless became prevalent (BENCE, R. and Udvarhelyi, É.T. 2013).

Three factors justified the selection of our case-study area: (1) On the vacant plots located in the immediate vicinity of the historical city centre commercial development took place in the middle of the 1990s, so the new spaces of consumption were formed not so much on the edge of the city but rather in its centre. These spaces became part of the survival strategies of homeless people (e.g. redemption of selective waste for money, begging). (2) Among Hungarian cities Kaposvár showed the third highest number of homeless people living on the streets without any shelter in 2012. According to our interview partners there are about 350-500 people in Kaposvár (population ca. 63,000) who spend the nights on the streets, in unoccupied hous- es or in abandoned industrial buildings. (3) With initiating the criminalisation of (aggressive) begging in 2004 the local government of Kaposvár was the first among countryside cities in Hungary where an anti-homeless law was accepted.

The reconquering of the historical citycentre (i.e. the exclusion of homeless people) took place parallel with the rehabilitation. In the planning phase of the project the local political elite introduced new, restrictive regulations and after the Hungarian Constitutional Court declared it as unlawful and initiated its termination the local charismatic leader and the economic elite urged the further application of these regulations. Local homeless people were very much aware of this. One of them says:

"There is a loophole, and they have found this loophole. Punish the homeless anyway. " (D. Homeless man)

The result of the procedure - financial penalties due to littering - is prison/detention since homeless people do not have the op- 
portunity to pay the penalty because they do not have a permanent, secure income (Wacqaunt, L. 2008c). At the same time referring to crime prevention policies a CCTV system (155 cameras) was put into service legitimized by the idea of the "safest city" (Belina, B. 2011; Coleman, R. 2005).

"...the devices are able to transmit an image around the clock... that will let our police officers..., be present at all points in Kaposvár at the same time" (Kaposvár mayor post 11/30/2015)

The main function of the CCTV is obviously to control and exclude the undesirable people from the observed places with banning certain activities (alcohol and drug consumption in the streets, sleeping, begging, scavenging in the street) and with banishing marginal individuals (homeless, Roma and the poor) from city centre. We agree with the conclusions of Coleman, R. (2004), namely that the visible consequences (the growing urban poverty and polarisation) of neoliberal policy can be hidden by this practice and marginalised people can be excluded from certain places of the city (Coleman, R. 2003, 2004, 2005).

After the urban renewal project was finished (seizing the opportunities provided by national legislation) the historical downtown areas of Kaposvár became nominated as "homeless-free zones" by local political leaders, restricting the use of public space by regulations. To ensure the compliance of the regulations the power of public area supervisors was increased similarly to the police officers. Thus, the protection of public spaces based on the principle of zero tolerance has not only been validated by cameras, but were also sustained by personal supervision (UdVARHELYI, É.T. 2013).

"I have asked the public area supervisors to effectively move around, do not tolerate drinking in public areas, sleeping in the bus stops, and to pay special attention to public spaces." (Interview with the mayor of Kaposvár 12/17/2014)

In addition, the local government bought and closed down with fences and gates a number of downtown buildings, thus, reducing the number of accessible properties for homeless people. However, survival possibilities of homeless people were reduced not only in the historical city-centre by the local political elite. An emblematic abandoned industrial property near the historic centre - which was also regularly used by interview partners as shelter for the night - was demolished and the remaining part was closed with private security guards controlling the area (Photo 2). However, the former "users" found a new shelter at another similarly abandoned industrial plot. The number of homeless people dropped in the areas under prohibition, as a result of the regulations, and some of the "known" homeless got into jail.

Selective waste collection remained an important source of income even after the rehabilitation, but now interview partners do it more at night and at the less frequented spots and just the day before the dustbins are being emptied. Begging meant often a shame to the interview partners so they do it only after having no food for more days, but the penalisation of the activity did not change their hab-

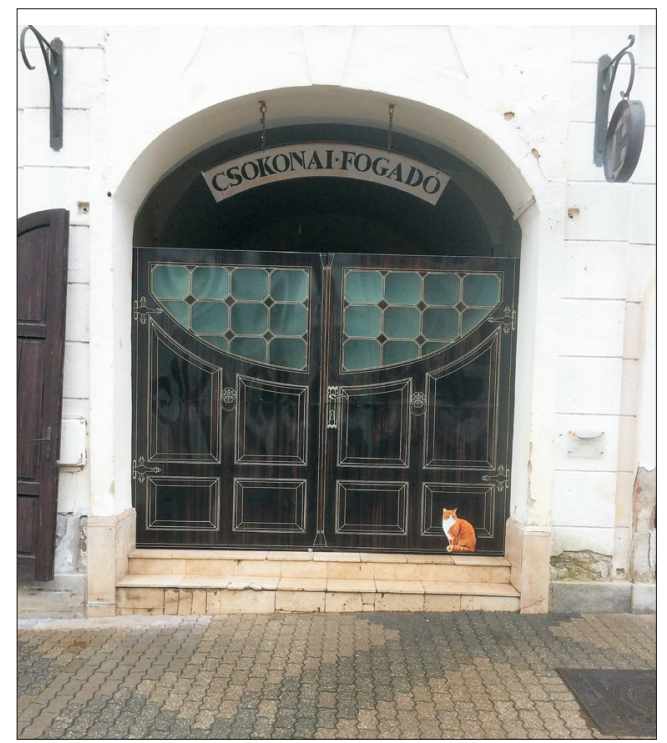

Photo 2. A vacant building (previous shelter for homeless) closed down by the local government in the centre of Kaposvár 
its. So despite the Constitutional Court's resolution the regulation has achieved its original purpose. According to our research findings the banning regulation had many other effects on the life of the city. Problems, conflicts related to homeless people appeared at many new places of the city outside the city-centre, also at places, which had not been affected by this problem before. Such places are: the edge of the city, housing estates and buildings used earlier for industrial purposes (Photo 3). The spatial displacement problem is clearly the result of the spatial exclusion policy. The regulations did not handle the real causes of homelessness (e.g. structural unemployment, lack of affordable housing) but criminalised the homeless people in certain areas with an attempt to make them invisible for the majority of the society. The acceptance of the regulation and the supporting behaviour of some part of the local population is due to the charismatic personality of the local politi-

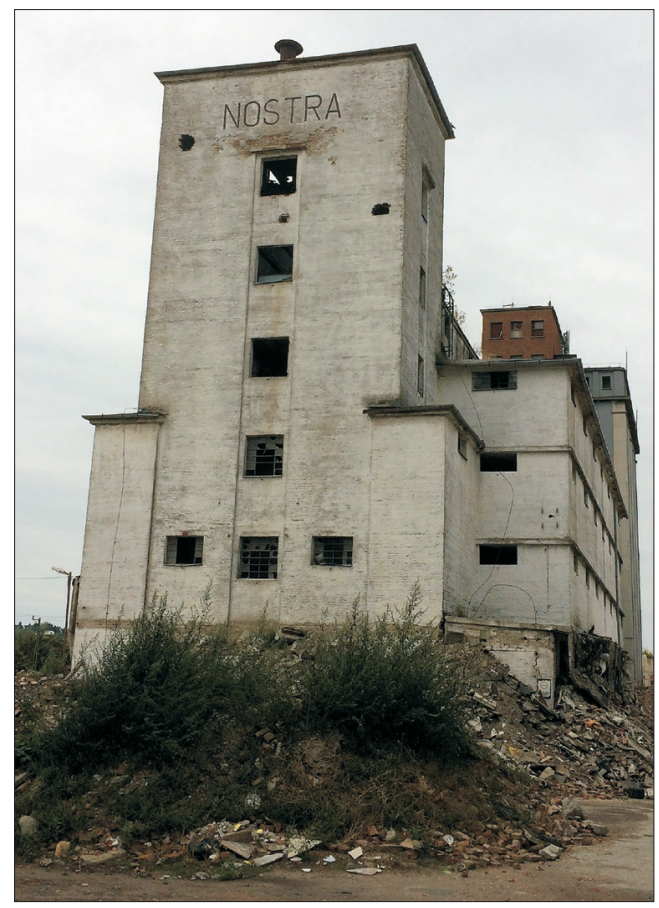

Photo 3. Former industrial building and shelter for homeless people before demolition in Kaposvár cal leader in our interpretation. He created a common platform around such problems which local citizens, investors and business owners and tradesman meet on a daily basis. The "homeless free downtown of Kaposvár" is a desirable thing for the users. While the living conditions of homeless continue to worsen, citing sociologist János Ladányi "this very serious problem is being moved from one place to another" ${ }^{\prime \prime}$ in Kaposvár.

\section{Discussion and conclusions}

The local political and economic elite in Kaposvár used the renewal mechanism of the historic city-centre to reclaim the control over (some) spaces of the city. They used urban regeneration (which was implemented from EU funds and investments from the private sector) as a tool to boost the economy of the city (Swyngedouw, E. et al. 2002; MAcLeod, G. 2011). The local mayor used his power and local legislative power to forbid the following activities in public spaces through systematic regulation-making processes: first "aggressive" begging (first time in Hungary), then scavenging, then "habitual use of the area of the historical centre" and finally "storing private property in a public space".

Besides making regulations more tools were used to narrow down the survival opportunities of homeless. They included city's architecture (spikes, benches), buying and closure or demolition of run-down inner-city buildings, transformation of homeless care, increasing security via CCTV and downtown patrols (Webster, W. 2009).

Alternative survival strategies evolved among the social workers and homeless who reacted to exclusion. The homeless began to use new unoccupied houses and abandoned industrial facilities as a shelter - provoking new responses from the elite - at the same time the helpers did not only help homeless with the day care but with providing them

\footnotetext{
${ }^{5}$ http://www.origo.hu/itthon/20080519-corvinsetanybontas-kikoltoztetes-a-getto-lakoinak-sorsa.html
} 
information about the police/public area supervisor "raids" too. Thus, not only spaces of exclusion have been constructed in Kaposvár over the past decade, but the spaces of resistance were formed too (TöröK, Á. and UDVARHELYI, É.T. 2006).

Neoliberal policies, revanchist attitudes resulted in the displacement of marginalised groups in Kaposvár in recent years (SмIтH, N. 1996; MacLeod, G. 2011). The nation-state delegated regulatory powers to the local level, which made it possible to prevent the access of unwanted people to the renewed historic downtown with reference to the safety of the citizens and also criminalised a wide range of everyday activities. Class-biased regulation-making process took place in Kaposvár which became a tool of the revanchist policy and this resulted in the reproduction of inequalities.

Anti-homeless measures that were intended to narrow down the survival possibilities of the most marginalised groups and were initiated by the local elite have achieved their objectives in many cases. Prohibition of scavenging is unconstitutional, but police and public supervisors in many cases unfairly penalise and bother homeless and not only in Kaposvár.

The extent of urban areas affected by the problem of homelessness has increased in Kaposvár, the previously not affected marginal parks of the downtown, housing estates, abandoned industrial sites, suburban areas have been reinterpreted as potential survival opportunities by many of the interview partners. ${ }^{6}$

Thus, class-based exclusion from urban space and criminalisation of certain behaviour leads to reproduction of inequality, not only locally but also on macro-social level, resulting in widening gap within the society. In this paper we explored the local factors in Kaposvár, however, similar social problems and mechanisms are known in Budapest and other Hungarian cities as well. The results of

\footnotetext{
${ }^{6}$ http://www.kaposvariujsag.hu/helyi-hireink/ kaposvar-rendszereto-ezert-ugyan-tesz-ahajlektalanokert-csak-nem-a-belvarosban
}

the neoliberal urban policy are clearly the reproduction of class structure, the handling of some individuals as second class citizens, the strengthening of the socio-economic position of the local political elite.

\section{REFERENCES}

BABBiE, E. 2001. A társadalomtudományi kutatás gyakorlata (The practice of social research). Budapest, Balassi Kiadó, 206-207, 276-277, 344-345.

BelinA, B. 2011. Disparitäten in der Stadt mittels Strafrecht regieren: governing through crime through space. In Urbane Diferenzen - Disparitäten innerhalb und zwischen Städten. Eds.: Belina, B. Gestring, N., Müller, W. and Sträter, D., Münster, Verlag Westfälisches Dampfboot, 115-131.

Bell, E. 2011. Criminal Justice and Neoliberalism. Basingstoke, New Palgrave Macmillan, York.

Bence, R. and Udvarhelyi, É.T. 2013. The growing criminalization of homelessness in Hungary - a brief overwiev. European Journal of Homelessness 7. (2): 133-134.

Bernt, M. and Colini, L. 2013. Exclusion, Marginalization and Peripheralization. Conceptual concerns in the study of urban inequalities. Working Paper, Erkner, Leibniz Institute for Regional Development and Structural Planning, 2013 Ekner, April 2013. www.irs-net. de/download/wp-exclusion-marginalization-peripheralization.pdf

Bockman, J. and Eyal, G. 2002. Eastern Europe as a Laboratory for Economic Knowledge: The Transnational Roots of Neoliberalism. American Journal of Sociology 108. (2): 310-352.

BRENNER, N. 2009. Open questions on state rescaling. Cambridge Journals of Regions, Economy and Society 2. $123-139$.

Cochrane, A. 2007. Understanding urban policy. A critical approach. Oxford, Blackwell.

Coleman, R. 2003. Images from a neoliberal city: the stata, surveillance and social control. Critical Criminology 12. 21-42.

Coleman, R. 2004. Watching the Degenerate: Street Camera Surveillance and Urban Regeneration. Local Economy 19. (3): 199-211.

Coleman, R. 2005. Surveillance in the city: Primary definition and urban spatial order. Crime Media Culture 1. (2): 131-148.

Cox, M. 1998. The local and the global in the new urban politics. Environment and Planning $D 16$ (5): 433-448.

Davis, M. 1992. Fortress Los Angeles: The militarization of Urban Space. In Variations on a Theme Park: The New American City and the End of the Public Space. Ed.: Sorkin, M., New York, Farraf, Straus and Giroux, 154-181.

Davis, M. 2006. City of Quarz: Excavating the Future in Los Angeles. London, Verso Books. 
Ellickson, C.R. 1996. Controlling Chronic Misconduct in City Spaces: Of Panhandlers, Skid Rows, and Public-Space Zoning. Faculty Scholarship Series, Paper 408. 1167-1246.

Feldman, L. 2006. From Vagrancy Law to Contemporary Anti-Homeless Policy. In Citizens Without Shelter. Homelessness, Democracy and Political Excusion. Ithaca, Cornell University Press, 27-56.

Földi, Zs. 2009. A társadalmi részvétel szerepe a városfejlesztés gyakorlatában - európai és hazai tapasztalatok (The role of community involvement in urban planning - the European and the national experience). Tér és Társadalom 23. (3): 27-43.

Harvey, D. 1989. From managerialism to entrepreneurialism: the transformation of urban governance under late capitalism. Geografiska Annaler 71. 3-17.

Harvey, D. 2005. A brief history of Neoliberalism. Oxford, Oxford University Press.

Harvey, D. 2006. Spaces of Global Capitalism. Towards a Theory of Uneven Geographical Development. London, Verso Books.

HiRT, S. 2013. Whatever happened to the (post)socialist city? Cities 32. 29-38.

Hirt, S., Sellar, C. and Young, C. 2013. Neoliberal Doctrine Meets the Eastern Block: Resistance, Appropriation and Purification in Post-Socialist Space. Europe-Asia Studies 65. (7): 1243-1254.

Ivanics, Zs. 2013. Bevezetés: Város és biztonság. (Introduction: City and security). In Kritikai városkutatás. Eds.: Jelinek, Cs., Bodnár, J., Czirfusz, M. and Grimesi, Z., Budapest, L'Harmattan Kiadó, 335-345.

Jessop, B. 2002. Liberalism, neoliberalism and urban governance: A state-theoretic perspective. In Spaces of Neoliberalism: Urban Restructuring in North America and Western Europe. Eds.: Brenner, N. and Theodore, N., Oxford, Blackwell, 105-125.

Kovács, Z. 2009. A szegénység és társadalmi kirekesztés térformái az alföldi városokban (Spatial forms of poverty and social exclusion in the towns of the Hungarian Great Plain). In Helyünk a világban - alföldi válaszok a globalizáció folyamataira. Eds.: Belanka, Cs. and Duray, B., IV. Alföld Kongresszus, Békéscsaba, 27-28. Nov. 2008. Békéscsaba, MTA RKK Alföldi Tudományos Intézet, 95-99.

KovÁcs, Z. and SzABó, B. 2015. Urban restructuring and changing patterns of socio-economic segregation in Budapest. In Socio-Economic Segregation in European Capital Cities: East meets West. Eds.: Tammaru, T., Marcińczak, S., van Ham, M. and Musterd, S., London-New York, Routledge, 238-260.

Kovács, Z., Wiessner, R. and Zischner, R. 2013. Urban Renewal in the Inner City of Budapest: Gentrification from a Post-socialist Perspective. Urban Studies 50. (1): 22-38.

Kovács, Z., Wiessner, R. and Zischner, R. 2015. Beyond gentrification: diversified neighbourhood upgrading in the inner city of Budapest. Geografie 120. (2): 251-274.
Kuenn, M. and Bernt, M. 2013. Peripheralization and power - theoretical debates. In Peripheralization. The Making of Spatial Dependencies and Social Injustice. Eds.: Fischer-TAHIR, A. and NAUMANN, N., Wiesbaden, Springer, 302-317.

Lees, L. 1994. Gentrification in London and New York: an Atlantic gap? Housing Studies 9. 199-219.

LEEs, L. 2000. A reappraisal of gentrification towards a 'geography of gentrification. Progress in Human Gentrification' 24. 389-408.

Lefebvre, H. 1995. The right to the city. In Writings on Cities. Ed.: Lefebvre, H., Cambridge, MA, Blackwell, 63-184.

Leitner, H. 1990. Cities in Pursuit of Economic Growth: The Local State as Entrepreneur. Political Geography Quarterly 9. (2): 146-170.

Letenyei L. 2004. Településkutatás (Settlement research). Budapest, L'Harmattan Kiadó-Ráció Kiadó, 95 p.

Lynch, P. 2002. Begging for Change. Homelessness and the Law. Melbourne, Melbourne University Law Review. http://www.austlii.edu.au/au/journals/ MULR/2002/35.html

MacLeod, G. 2011. Urban Politics Reconsidered: Growth Machine to Post-democratic City? Urban Studies 48. (12): 2629-2660.

Madden, K. 2005. How to turn a place around? A Handbook for Creating Successful Public Spaces. New York, Project for Public Spaces Inc., 119-134.

Mahs, J. von 2005. The Sociopatial Exclusion of Single Homeless People in Berlin and Los Angeles. American Behavioral Scientist 8. 928-960.

Mason, J. 2005. A kvalitatív kutatás (The qualitative research). Budapest, Jószöveg Mühely Kiadó, 14-16.

Massey, D. 2008. For Space. London, SAGE Publications Ltd.

May, J. 2000. Of nomads and vagrants: single homelessness and narratives of home as place. Enviroment and Planning D. 18. 737-759.

Misetics, B. 2010. Otthontalan, csupa-csősz világ (Homeless, totally supervised world). Replika 71. (2): 29-44.

Mitchell, D. 1995. The End of Public Space? People's Park, Definitions of the Public, and Democracy. Annals of the Association of American Geographers 85. (1): 108-133.

Mitchell, D. 1997. The annihilation of space by law: the roots and implications of anti-homeless laws in the United States. Antipode 3. 303-335.

Mitchell, D. and Heynen, N. 2007. The Geography of Survival and the Right to the City: Speculations on Surveillance, Legal hmovation, and the Criminalization of hitervention. Urban Geography 6. 611-632.

Moloтосн, H. 1976. The city as a growth machine. American Journal of Sociology 82. (2): 309-330.

NAGY, E. 2005. Urban development in post-transition Hungary: emerging social conflicts as constraints for a locality. Geographia Polonica 78. (1): 23-37. 
Nagy, E. 2012. Verseny vagy kiegyenlítés? Az európai várospolitika neoliberális fordulata és a helyi tervezési-fejlesztési gyakorlatok „projektesítése” (Competition or equalization? The neoliberal turn of European urban policies and the 'projectification' of local planning and development practices). In A társadalomföldrajz lokális és globális kérdései. Tiszteletkötet Dr. Mészáros Rezső professzor 70. születésnapja alkalmából. Ed.: Pál, V., Szeged, SZTE TTIK Gazdaság- és Társadalomföldrajz Tanszék, 54-67.

NAgY, E. and Timár, J. 2010. Social deficits of revitalization: production of urban space in the „East” and in the "West". In Regional responses and global shifts: actors, institutions and organisations. Ed.: BEAUCLAIR, A., Publication on an international conference, 24-26 May 2010. Pécs, University of Pécs, 225 p.

Nagy, E., Timár, J., Nagy, G. and Velkey, G. 2015. A társadalmi-térbeli marginalizáció folyamatai a leszakadó vidéki térségekben (The processes of socio-spatial marginalization in declining rural spaces). Tér és Társadalom 29. 1. 35-52.

NeAL, Z.P. 2010. Locating Public Space. In Common Ground? Readings and Reflections on Public Space. Eds.: Orum, A.M. and ZAChary, P.N., London, Routledge, 1-13.

O'Sullivan, E. 2007. 'Criminalizing People who are Homeless?' Homeless in Europe. Brussels, Feantsa, Summer (3-4): 1-20.

RACo, M. 2014. Delivering Flagship Projects in an Era of Regulatory Capitalism: Stated-led Privatization and the London Olympics 2012. International Journal of Urban and Regional Research 38. 176-197.

SAssen, S. 1996. Whose City Is It? Globalization and the Formation of New Claims. Public Culture 8. 205-223.

Shields, S. 2012. The International Political Economy of Transition - Neoliberal Hegemony and Eastern Central Europe's Transformation. London, Routledge.

Sмiтh, N. 1996. The new urban frontier. Gentrification and the revanchist city. London and New York, Routledge.

Soja, E.W. 2000. Postmetropolis. Cambridge, Blackwell.

Soja, E.W. 2010. Seeking Spatial Justice. Minneapolis, University of Minnesota Press.

Steinar, K. 2005. Az interjú - Bevezetés a kvalitatív kutatás interjútechnikáiba (The interview - Introduction to interview-making techniques of qualitative research). Budapest, Jószöveg Műhely Kiadó, 79-80.

Swyngedouw, E., Moulaert, F. and Rodriguez, A. 2002. Neoliberal Urbanization in Europe: LargeScale Urban Development Projects and the New Urban Policy. Antipode 34. 542-577.

Szelényi, I. and Csillag, T. 2015. Drifting from Liberal Democracy: Traditionalist/Neo-conservative Ideology of Managed Illiberal Democratic Capitalism in Post-communist Europe. Intersections. East European Journal of Society and Politics 1. 18-48.
TImár, J. and Nagy, E. 2007. A középvárosi dzsentrifikáció társadalmi hatásai a posztszocialista Magyarországon (The social effects of gentrification in a middle-sized town in post-socialist Hungary). In A történelmi városközpontok átalakulásának társadalmi hatásai. Ed.: Enyedi, Gy., Budapest, MTA Társadalomkutató Központ, 293-319.

Tosi, A. 2007. Homelessness and the Control of Public Space-Criminalising the Poor? European Journal of Homelessness 1. 225-236.

TöröK, Á. and Udvarhelyi, É.T. 2006. Egy tiszta város piszkos lakói avagy „,aluljárótakarítási szertartások” Budapesten (A clean city dirty residents or „underpass-cleaning rituals" in Budapest). In Kultúrák között - Hommage A. Boglár Lajos. Eds.: Gergely, A.A., Papp, R. and Prónai, Cs. Budapest, Nyitott Könyvmúhely, 477-500.

UDVARHELYI, É.T. 2013. (In) justice on the streets: The long housing crisis in Hungary from above and below. New York, City University of New York, 316 p.

VÁrAdi, M.M. and VIRÁG, T. 2015. A térbeli kirekesztés változó mintái vidéki terekben (The changing patterns of spatial exclusion in rural areas). Szociológiai Szemle 25. (1): 89-113.

Waceuant, L. 1996. The rise of Advanced Marginality: Notes on its Nature and Implications. Acta Sociologica 39. 121-139.

WACQUANT, L. 1999a. Urban Marginality in the coming Millennium. Urban Studies 36. (10): 1639-1647.

Wacquant, L. 1999b. How Penal Common Sense Comes to Europeans: Notes on the Transatlantic Diffusion of the Neoliberal Doxa. European Societies 1. (3): 319-352.

Wacquant, L. 2001. The Penalisation of Poverty and the rise of Neo-Liberalism. European Journal on Criminal Policy and Research 9. (4): 401-412.

Wacquant, L. 2007. Territorial stigmatization in the age of advanced marginality. Thesis Eleven 91. 66-77.

Wacquant, L. 2008a. The Militarization of Urban Marginality: Lessons from the Brazilian Metropolis. International Political Sociology 1. (2): 56-74.

Wacquant, L. 2008b. Urban Outcasts: A Comparative Sociology of Advanced Marginality. Cambridge, Polity.

Wacquant, L. 2008c. Ordering Insecurity. Social Polarization and the Punitive Upsurge. Radical Philosophy Review 11. (1): 1-19.

Wacquant, L. 2009. Punishing the Poor: The Neoliberal Government of Social Insecurity. Durham and London, Duke University Press.

WACQUANT, L. 2012. Three steps to a historical anthropology of actually existing neoliberalism. Social Anhropology 20. 66-79.

Wacquant, L. 2014. Marginality, Ethnicity and Penality in the Neoliberal City: An Analytic Cartography. Ethnic \& Racial Studies 37. (10): 1687-1711.

Webster, W. 2009. CCTV policy in the UK. Surveillance $\mathcal{E}$ Society 6. (1): 10-22. 